\title{
Frequency Analysis of Genesis Risk In Construction Projects
}

\author{
Anita Rauzana \\ (Staff of Civil Engineering Department, University of Syiah Kuala, Banda Aceh, Indonesia)
}

\begin{abstract}
Contractor as general constructions supervisors face risk factors that could affect performance and hinder the success of a construction project. Many contracting companies along with the advent of growing development in Banda Aceh to make the contractor should be able to maintain its performance in order to compete with other contractors. The subject matter and the question in this study are what the risk factors that can affect the performance of the contractor Banda Aceh in the implementation of construction projects. The purpose of this study to identify risk factors that have a frequency of occurrence is very frequent in the implementation of construction projects in Banda Aceh experienced contractor in the execution of construction projects in the province of Aceh. The scope of this research is limited to the risks accepted by the contractor Banda Aceh Non-small qualification (qualifying grade 5) in carrying out construction projects. Risk factors reviewed is a risk factor in the implementation of construction projects in general. The collection of primary data collected through the distribution of questionnaires to the respondents that the small non-qualified contractor who lives in Banda Aceh. As for the secondary data such as the names of the contracting company based in Banda Aceh. Data processing is done by the analysis of test reliability, frequency analysis and frequency analysis of the index. Data processing is done by statistical methods and computational tools utilizing the software Statistical Package for Social Sciences (SPSS 16.0 for Windows) and Microsoft Excel. Based on the analysis of the frequency index gained 10 key risk factors that have a frequency of occurrence is very common in the implementation of construction projects in Banda Aceh experienced contractor in the execution of construction projects.
\end{abstract}

Keywords: Risk, frequency index, contractors, project, construction

\section{Introduction}

Banda Aceh is one of the cities in the province of Aceh in Indonesia, which is undergoing rapid development growth progress. This can be seen by many developing or the emergence of efforts in the field of construction industry, both corporate contractors (contractor) and corporate planners and construction supervisor (consultant). Performance contracting is a result of work is achieved by the contractor in executing a construction project. Performance is based on skills, experience and sincerity, and the time, as compared to predetermined targets. If a construction project a success then it could be said that the performance of the contractor in the execution of the project well and vice versa. Risk factors in construction projects can arise from a variety of sources, and vary both in the likelihood and the impact on the success of the construction project. In order to carry out the construction projects on time according to the schedule, the contractor managing the construction in general will face the risk factors that can hinder the success of the construction project and affect its performance.

In this study, the research object is the contractor Banda Aceh, which are at issue and the question in this research is the key risk factors that may affect any contractor performance Banda Aceh in the implementation of construction projects. The purpose of this study was to identify risk factors that have a frequency of occurrence is very frequent in the implementation of construction projects experienced by the contractor Banda Aceh in the implementation of construction projects in the province of Aceh. The scope of this research is limited to the risk factors who received non-small contractor qualification (qualifying grade 5) in carrying out construction projects in Banda Aceh. These risk factors are reviewed is a risk factor in the implementation of construction projects in general.

The research method used is through several stages, starting with the formulation of the problem, the study of literature, primary data collection and secondary data collection, data processing using statistical software, and data analysis and discussion.

In order to achieve the intended objectives, it is necessary primary and secondary data. Primary data was collected through the distribution of questionnaires, the respondents is the non-qualifying small contractors who live in Banda Aceh. Secondary data such as names of contractors who are registered as members of the association GAPENSI (Joint Managing Construction in Indonesia).

Data processing is done by the analysis of test reliability, frequency analysis and frequency analysis of the index. Data processing is done by statistical methods and computational tools utilizing the software Statistical Package for Social Sciences (SPSS 16.0 for Windows) and Microsoft Excel. Based on the index value frequency is the objective of this research have been achieved with the acquisition of 10 (ten) risk factors that 
have a frequency of occurrence is very frequent in the implementation of construction projects experienced by the contractor Banda Aceh. The benefit of this study for researchers expected to increase knowledge of the risk factors contained in the implementation of construction projects, especially the risk factors that have a frequency of occurrence is very frequent in the implementation of construction projects that could affect the successful implementation of construction projects. Meanwhile, contractors are expected to be input on the risk factors that have a frequency of occurrence is very frequent in the implementation of construction projects so that these risk factors may be more, in order to improve the performance of the contractor.

\section{Literature Review}

\subsection{Definition and Types of Construction Projects}

Shah (2004: 12) defines the notion of a series of projects are planned and executed in sequence with logic and using many types of resources are constrained by the dimensions of cost, quality, and time. Meanwhile, according to Oberlender (2000: 4), project is an activity undertaken to produce something that is expected of a request. Projects may include the design, construction, or a combination of design and construction.

Ervianto (2005: 14) explains the construction project can be divided into two groups of buildings, namely:

1. Buildings: homes, offices, factories and others. The characteristics of the building are:

a. Construction projects produce where people work or live;

b. Work is carried out on a relatively narrow and foundation conditions generally known;

c. Management is needed, especially for the Progressing work.

2. Civil construction: roads, bridges, dams, and other infrastructure. The characteristics of the building are:

a. Construction projects to be implemented to control nature for the interest of men;

b. The work carried out on site wide or long and foundation conditions are very different from each other in a project;

c. Management is required to solve the problem.

Schexnayder (2003: 37) generally classifies four types of construction projects,

Namely:

1. Construction of residential

Construction includes residential homes and apartments.

2. Commercial Construction

Construction includes commercial buildings, shopping malls, schools and libraries and so on.

3. Construction industry

Construction industry includes mills, oil refineries, pipelines, power generation facilities, and other facilities required by public services and basic industries.

4. Heavy engineering construction

Heavy engineering construction includes dams and levees, canals, roads, bridges, railways and tunnels.

\subsection{Parties Involved in Construction Projects}

Husen (2009:16), states that in order for the wants and needs of each party in the project can be realized in a concerted effort to achieve the goals and objectives, it is necessary to identify the organization or individual (stakeholder), both from internal and external, which will play a role affecting the project and should be anticipated during the project. Stakeholder project generally described as below.

- Project Manager: a person responsible for managing the project.

- Customer (customer): a person / organization to use the project product.

- Project Organization: hierarchy / order of individual tasks and authority.

- Sponsor: provider of funding for the project.

\subsection{Definition Construction Project Success}

Kerzner (2006: 7) mentions the definition of success of the project to change the perspective or judgment, which 20 years ago, the success of the whole project is defined as the completion of the project activity in terms of time, cost and quality. At this time, the definition of success of the project has been modified to include the completion of all work items include:

- In the period of time allotted,

- With costs already budgeted,

- Meets the performance (quality) / level specification,

- Acceptance of the good by the user,

-With the change in scope and the minimum acceptable joint,

-Without disturbing the main work flow of the organization, 
- Without changing the corporate culture.

\subsection{Factors Risk in Construction Projects}

Laia (2010: 3) understanding of the risk factors mentioned in the context of the project can be defined as a translation of the unfortunate consequences, both financially and physically, as a result of decisions made or the result of environmental conditions the location of an activity. Santoso (2004: 4) mentions the risk factors contained in construction projects are many and varied, but not all risk factors need to be predicted and considered to start a project because it will take a long time. Risk factors affecting the implementation of construction projects and their source can be seen in Table 2.1.

Tabel 2.1 Risk Factors Affecting Implementation of Construction

\begin{tabular}{|c|c|c|c|}
\hline & Categories & Risk Factors & Sources \\
\hline \multirow[t]{4}{*}{1} & \multirow{4}{*}{ Physical } & Natural disasters & (Ahmed, 1999) \\
\hline & & Land surface conditions & (Ghosh, 2004) \\
\hline & & Groundwater conditions & (Ghosh, 2004) \\
\hline & & Uncertainty conditions in the field & (Ghosh, 2004) \\
\hline \multirow{7}{*}{2} & \multirow{7}{*}{ Labor and Experts } & Skills and expertise & (Kangari, 1995) \\
\hline & & discipline & (Suharti, 2009) \\
\hline & & productivity & (Ahmed, 1999) \\
\hline & & Less compact team work & (Suharti, 2009) \\
\hline & & Arguments workers & (Ahmed, 1999) \\
\hline & & Lack of workforce & (Laia, 2010) \\
\hline & & Labor strike & (Ahmed, 1999) \\
\hline \multirow{3}{*}{3} & \multirow{3}{*}{ consultant } & Design errors & (Ahmed, 1999) \\
\hline & & Incomplete design data & (Laia, 2010) \\
\hline & & Late information from planners & (Suharti, 2009) \\
\hline \multirow{2}{*}{4} & \multirow{2}{*}{ Owner } & Financial Failure owner & (Ahmed,1999) \\
\hline & & change order & (Suharti, 2009) \\
\hline \multirow{4}{*}{5} & \multirow{4}{*}{ Material } & Delay in delivery & (Suharti, 2009) \\
\hline & & Damage during shipment & (Suharti, 2009) \\
\hline & & Damage during storage & (Ghosh, 2004) \\
\hline & & Low quality material & (Suharti, 2009) \\
\hline \multirow{4}{*}{6} & \multirow{4}{*}{ Equipment } & Productivity and efficiency & (Ahmed, 1999) \\
\hline & & Lack of equipment & (Suharti, 2009) \\
\hline & & Age tools unsuitable & (Suharti, 2009) \\
\hline & & damage to equipment & (Suharti, 2009) \\
\hline \multirow{6}{*}{7} & \multirow{6}{*}{ Construction Process } & $\begin{array}{l}\text { Changes in construction work due to difficult to } \\
\text { implement }\end{array}$ & (Ahmed, 1999) \\
\hline & & $\begin{array}{l}\text { The quality of work is not good / quality of } \\
\text { work }\end{array}$ & (Ahmed, 1999) \\
\hline & & communication problems & (Suharti, 2009) \\
\hline & & coordination problems & (Suharti, 2009) \\
\hline & & The number of real jobs & (Kangari, 1995) \\
\hline & & The method implementation is wrong & (Laia, 2010) \\
\hline 8 & Approximately & Access to the project site & (Ahmed, 1999) \\
\hline
\end{tabular}


Frequency Analysis of Genesis Risk In Construction Projects

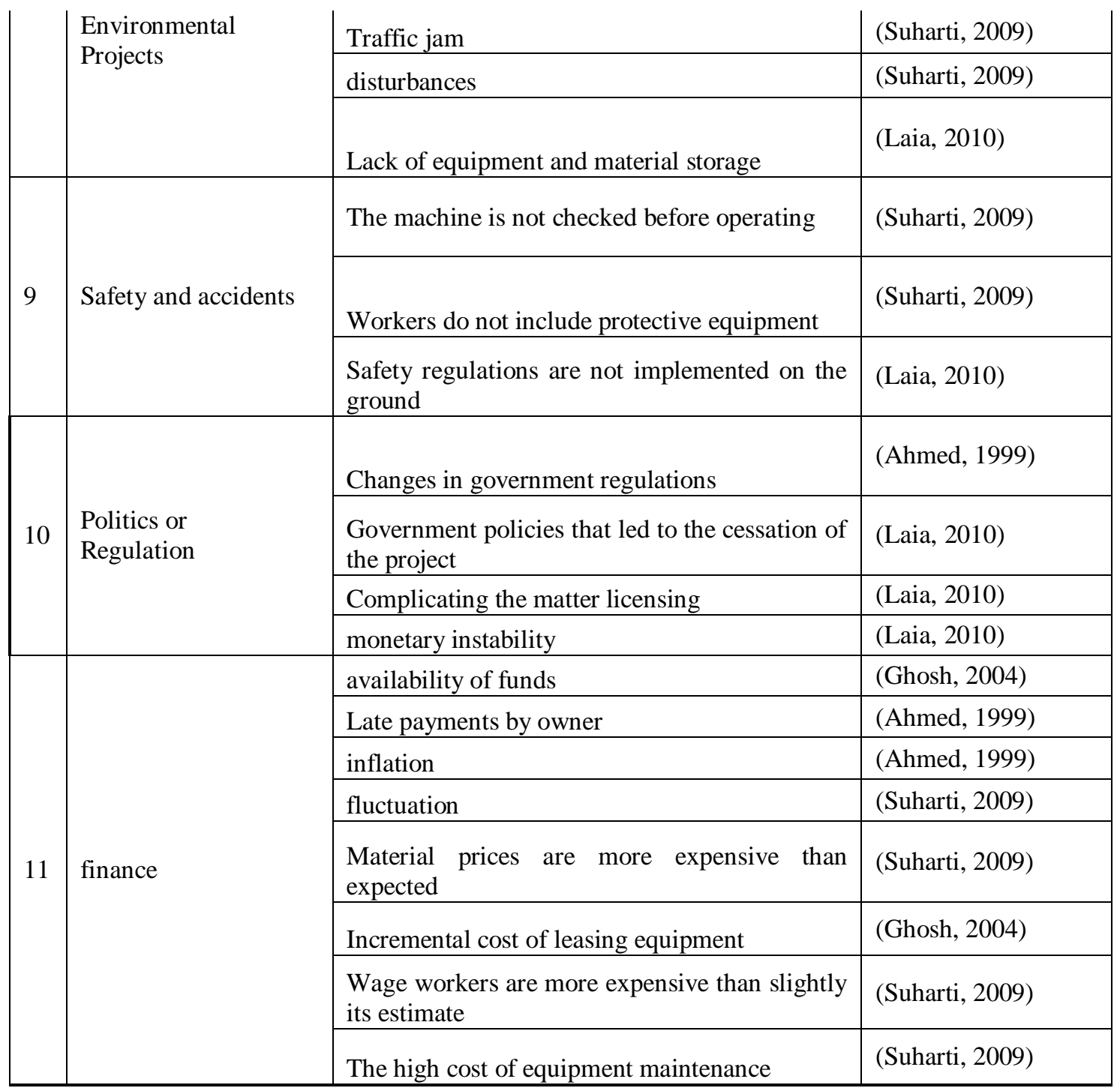

\subsection{Project Performance}

Koncoro (1999: 7) mentions the performance of the project is how the project work by comparing the results of the real work to estimate the workings of the labor contract agreed upon by the owner and the contractor.

\subsection{Data Collection}

\section{Research Methodology}

Data used for research activities include primary data and secondary data. Primary data was obtained through a questionnaire survey and secondary data from a list of company names listed contractor who live in Banda Aceh.

\subsubsection{Scale of measurement}

Measurement scales to the questionnaire using an ordinal scale. Supangat (2007: 11) explains the sequence of ordinal scale is numeric symbols or codes of significant levels of sequence can be started from the most negative to the most positive or otherwise. Measurements in this study was conducted to measure are measurement to measure the frequency of occurrence of risk factors. Details of measurement to measure the frequency of occurrence of risk factors, the scale is a scale of 1 (never), scale 2 (rarely), scale 3 (fairly often), scale 4 (often), and the scale of 5 (very often). 


\subsubsection{Design the questionnaire}

The questionnaire is designed in two parts: the respondent characteristics and risk factors affecting the implementation of construction projects.

A. Characteristics of respondents and decryption project

In this section, the questions are provided aims to determine the long experience of the respondents work in the construction, education, respondent, respondent experience, and others. A questionnaire was open-ended.

B. Risk factors affecting the performance of the contractor on the construction project implementation. This section deals with the risk factors affecting the implementation of construction projects.

\subsubsection{Distribution of the questionnaire}

Questionnaires conducted by distributing questionnaires to the respondents by way of direct transfer, with the intention of asking for the willingness of the respondents fill out the questionnaire. If the respondents are busy, the researchers left the questionnaire, and then asked that filled directly by the respondent and taken after a lapse of a few days. The data was collected during 1.5 months.

\subsubsection{Target respondents}

A target respondent in this study is the head of the company or the project manager of a construction company based in Banda Aceh. Target respondents restricted to contractors who are registered as members GAPENSI qualified Non-Small (qualifying grade 5). Determination of the minimum number of samples is done using Slovin formula in equation (2.1) with the analysis of fault tolerance allowed is $10 \%$. Step sample calculations performed as follows:

$$
n=\frac{N}{1+\left(N \cdot e^{2}\right)}=\frac{35}{1+\left(35 \times 0,1^{2}\right)}=26
$$

\subsection{Data Processing}

Processing of research data using the help of a software program Statistical Package for Social Sciences (SPSS 16.0 for Windows) and Microsoft Excel. The results of this treatment in the form of charts and tables that is easier to understand. In addition, Microsoft Excel and Microsoft Word are also used to assist the analysis of research data.

\subsubsection{Reliability analysis}

According Arikunto (2002: 154), reliability analysis is points to the notion that something instrument trustworthy enough to be used as a data collection tool. Reliability analysis commonly used is the analysis Cornbach Alpha (c-alpha). The test using C-Alpha coefficients must be greater or equal to 0.6 is considered to test the value of the appropriateness of the questionnaire were used. The formula used is as follows:

$$
r=\frac{k}{(k-1)}\left[1-\frac{\sigma_{b}^{2}}{\sigma_{1}^{2}}\right]
$$

where:

$r=$ reliability of the instrument

$\mathrm{k}=$ number of items questions

$\sigma_{b}^{2}=$ Variant grain

$\sigma_{1}^{2}=$ Total variance

The formula for the variance and variance items total:

$$
\begin{aligned}
\sigma_{1}^{2} & =\frac{\sum X t^{2}}{n}-\frac{\left(\sum X t\right)^{2}}{n^{2}} . \\
\sigma_{b}^{2} & =\frac{J k i}{n}-\frac{J k s}{n^{2}} \ldots \ldots \ldots \ldots \ldots \ldots \ldots \ldots \ldots
\end{aligned}
$$

Where:

$$
\begin{aligned}
& \sigma_{1}^{2}=\text { Total variance } \\
& \sigma_{b}^{2}=\text { Variant grain }
\end{aligned}
$$


$\Sigma \mathrm{Xt}^{2}=$ total number of respondents Squares

$\Sigma \mathrm{Xt}=$ total number of respondents

$\mathrm{JKi}=$ sum squared whole grains

$\mathrm{Jks}=$ sum of squares subject

$\mathrm{n} \quad=$ number of respondents

\subsubsection{Analysis of Frequency Index (FI)}

Frequency index shows the frequency of risk factors that affect the performance of the contractor Banda Aceh. For frequency analysis calculation index (FI) using the formula in the following equation (Bernstein and Bernstein, 1999 quoted by Long, et al, 2008: 369)

Frequency Index (F.I) $=\frac{\sum_{i=1}^{5} a_{i} n_{i}}{5 N}$

Where:

$\mathrm{i}=$ index response categories $(1,2,3,4$ and 5$)$

$a_{i}=$ weights associated with the response to the value of $i(1,2,3,4,5$ respectively)

$\mathrm{n}_{\mathrm{i}}=$ frequency of response to $\mathrm{i}$ as a percentage of total respondents for each factor

$\mathrm{N}=$ total number of respondents

\section{Results And Discussion}

\subsection{Identification of Risk Factors Affecting Performance Contractors}

The questionnaire in this study is open in the hope that getting a new factor of the factors influencing the performance of the contractor in the execution of the project. After distributing the questionnaire within 1.5 months was not obtained new factor affecting the performance of the contractor in the execution of Banda Aceh construction projects. All of the factors that affect the performance of the contractor in the execution of projects are analyzed based on respondents' answers. The analysis used is:

1. Reliability analysis,

2. Frequency analysis,

3. Analysis of frequency index,

\subsection{Analysis of reliability}

To test that the questionnaire has been compiled be used as a tool to achieve the objectives of this research are used by Cronbach Alpha reliability analysis. The testing using Cronbach Alpha coefficients must be greater or equal to 0.6. Calculation of reliability analysis carried out with the help of Statistical Package for Social Sciences (SPSS 16.0 for Windows). Calculation of Cronbach Alpha coefficients for the frequency of occurrence of the risk is 0.895 which is greater than 0.6. This means that the questionnaire could be used as a tool to achieve the objectives of this study.

\subsection{Analysis of frequency index (FI)}

This section shows the results of the questionnaire data processing through Microsoft Excel program to index the frequency of occurrence of the risk factors. Based on the analysis of the FI, it is known 10 (ten) risk factors that have a frequency of occurrence is very frequent in the implementation of construction projects experienced by the contractor Banda Aceh. Tenth risk factors can be seen in Table 4.5.

Table 4.5 Ten Risk Factors Having Frequency incident Very Often in Construction Project Execution

\begin{tabular}{|l|c|c|}
\hline \multicolumn{1}{|c|}{ Factors } & FI & Rank \\
\hline Change order & 0,651 & 1 \\
\hline Safety regulations are not implemented on the ground & 0,578 & 2 \\
\hline Material prices are more expensive than expected & 0,565 & 3 \\
\hline Disturbances & 0,547 & 4 \\
\hline Late information from planners & 0,543 & 5 \\
\hline damage to equipment & 0,507 & 6 \\
\hline The high cost of equipment maintenance & 0,501 & 7 \\
\hline Inflation & 0,498 & 8 \\
\hline Workers do not include protective & 0,49 & 9 \\
\hline Less number of real jobs & 0,488 & 10 \\
\hline
\end{tabular}




\section{Conclusions}

The conclusions that can be drawn from the results of a study of risk factors that affect the performance of the contractor Banda Aceh in the implementation of construction project are as follows:

Based on the calculation of frequency index, gained 10 risk factors that have a frequency of occurrence is Very frequent in construction experienced by contractors Banda Aceh, namely:

1. Change order has a value of 0.651

2. Safety regulations are not is implemented on the ground has a value of 0.578

3. Material prices are more expensive than expected has a value of 0.565

4. Disturbances has a value of 0.547

5. Late information from planners has a value of 0.543

6. Damage to equipment has a value of 0.507

7. The high cost of equipment maintenance has a value of 0.501

8. Inflation has a value of 0.498

9. Workers do not include protective has a value of 0.49

10. Less number of real jobs has a value of 0.488

\section{References}

[1] Ahmed, S. M, 1999, Risk Management Trends in the Hong Kong Construction industry : A Comparison of Contractors and Owners Perception, Journal of Engineering, Construction and Architectural Management, 6, pp. 225-234

[2] Arikunto, S., 2002, Research Procedures, PT. Rineka Cipta, Jakarta.

[3] Ervianto, 2005, Project Management construction, Andi, Yogyakarta.

[4] Ghosh, S, 2004, Identifying and Assessing the Critical Risk Factors in A Underground Rail Project in Thailand : A Factor analysis Approach, International Journal of Project Management, 22, pp. 633-643.

[5] Husen, A, 2009, Project Management Planning, Scheduling and Project Control, Andi, Yogyakarta.

[6] Kangari, R, 1995, Risk Management Perceptions and Trends of U.S Construction, Journal of Construction Engineering and Management, 121, pp 422-429.

[7] Kerzner, H, 2005, Project Management - A System Approach to Planning, Scheduling, and Controlling, John Wiley \& Sons, New York.

[8] Koncoro, A, H, 1999, Effect of Offering Document Quality Of Road Construction Project Performance Highways in Java, majoring in Civil Engineering Construction Management, University of Indonesia, Jakarta.

[9] Laia, B, P, 2010, Risk Identification and Response Project Apartment in Surabaya, Cross-Line Bachelor of Civil Engineering Department of Institute of Technology November, Surabaya.

[10] Long,. 2008, Delay and Cost Overruns in Vietnam Large Construction Project : A Comparison with Other Selected Countries, Korean Society of Civil Engineers Journal of Civil Engineering, Vol 12, pp. 367-377.

[11] Oberlender, G. D., 2000, Project Management for Engineering And Construction, Mc Graw Hill.

[12] Schexnayder, C. J. dan Mayo, R. E., 2003, Construction Management Fundamental, Mc Graw Hill.

[13] Suharti, A, 2009, Project Risk Factors : Case Study of Ministry of Education Project, A Project Report Submitted in Partial Fulfillment of the Requirements for the Award of the degree of Master of Science, Malaysia.

[14] Supangat, A, 2007, Statistics: the Descriptive Study, Inference, and Non Parametik, Kencana Jakarta.

[15] Shah, M. S, 2004, Project Management-Ways of Managing Projects, Scholastic Press, Jakarta 